\title{
THE SPECIES COMPOSITION OF TRUE BUG ASSEMBLAGES EXTRACTED WITH BERLESE FUNNELS (DATA TO THE KNOWLEDGE ON THE GROUND-LIVING HETEROPTERA OF HUNGARY, № 1)
}

\author{
D. RÉDEI ${ }^{1}$ \\ e-mail:dredei@freemail.hu \\ L. HUFNAGEL ${ }^{2}$ \\ e-mail:hufnagel@kee.hu \\ ${ }^{1}$ Department of Entomology, Faculty of Horticultural Sciences, \\ Szent István University, H-1118 Budapest, Ménesi út 44, Hungary \\ (phone / fax: +36-1-372-0125) \\ ${ }^{2}$ Department of Mathematics and Informatics, Faculty of Horticultural Sciences, \\ Szent István University, H-1118 Budapest, Villányi út 29-33, Hungary \\ (phone: +36-1-372-6261; fax: +36-1-466-9273) \\ (Received $21^{\text {th }}$ March 2003; accepted $15^{\text {th }}$ May 2003)
}

\begin{abstract}
A rich collection of Heteroptera extracted with Berlese funnel by Dr. I. Loksa between 19531974 in Hungary, has been examined. Altogether 157 true bug species have been identified. The great majority of them have been found in very low number, there are only 27 species of which more than 10 adult individuals have been found. Some species considered to be rare or very rare in Hungary have been collected in relatively great number (Ceratocombus coleoptratus, Cryptostemma pusillimum, C. waltli, Acalypta carinata, A. platycheila, Loricula ruficeps, Myrmedobia exilis). The three families, which are more or less rich in species and have the highest ratio of extracted species, were Rhyparochromidae, Tingidae and Nabidae. Out of them, the family Rhyparochromidae has been found to be most diverse and most characteristic at the ground-level. Individuals of the families Tingidae, Hebridae and Rhyparochromidae have been found in greatest number. The occurrence of the lace bug Campylosteira orientalis Horváth, 1881 in Hungary has been verified by a voucher specimen. In respect to the environmental changes through the country, parallel changes have been observed in the zoogeographical distribution of the ground-living bugs.
\end{abstract}

Keywords: Heteroptera, ground-level, Berlese funnel, species composition, zoogeography

\section{Introduction}

The majority of the terrestrial heteropterans can be collected from plants in great number by the usual methods for Heteroptera collecting (sweep-netting, beating etc.). Collecting bugs from the ground-level needs great effort and generally has trifling result compared with collecting from the vegetation. Therefore, the species occurring mostly or exclusively on the ground usually escape the zoologists' attention. The methods for collecting ground-living invertebrates (pitfall trap, sifting, Berlese funnels etc.) are only occasionally used by heteropterologists. Consequently, our knowledge on the faunistical, ecological, cenological data of species occurring mostly or exclusively on the ground is far poorer than that of species collected regularly in great number from the vegetation.

On this account, the authors examined numerous materials and identified a great number of true bugs collected in Hungary with Berlese funnels and pitfall traps. The present work - which is the first part of a series of publications - deals with the true 
bugs collected with Berles e funnel over 20 years in Hungary. Because of the identical way of collecting, the samples can be well compared on the basis of the true bugs found in them. In present paper the faunistic data and general observations on the species compositions as well as the zoogeographical analysis of Loksa's material are given.

\section{Review of literature}

The Heteroptera fauna of Hungary was investigated only sporadically before 1870 . The first researcher was G. Horváth, who published numerous taxonomical, faunistical, ethological etc. data to the knowledge of the true bugs of Hungary from 1870 until his death in the year of 1937.

The results of the early exploration of the Hungarian fauna was summarized in a great and unique work, Fauna Regni Hungariae, which listed all of the animals known from the country at the time. The part „Hemiptera” was compiled by Horváth [39], who later published also additional data [41].

The organized research of the fauna of Hungary, especially in the protected areas, started after the Second World War. One of the first results was the volume Bátorliget élövilága [The Natural Life of Bátorliget] in 1953, which presented data on the flora and fauna of the Bátorliget Nature Reserves and listed 107 heteropteran species from the area [29]. Later some works dealing with the true bugs of certain Hungarian areas $[10,28]$ and the species of some groups of Heteroptera $[11,12,13,16,30,31]$ were also published. Some of them provide data on some ground-inhabiting species, too.

The monumental work, Fauna Hungariae has a goal to provide keys for the identification of all the animals occurring in Hungary. Five booklets of the series dealing with parts of the order Heteroptera have been published up to now [14, 32, 60, $62,64]$, and a further booklet [45] is under publication.

In the $1970 \mathrm{~s}$, after the establishment of the first Hungarian national parks, the investigations of the fauna of these areas started with renewed effort. The results of the research are published in the series Natural History of the National Parks of Hungary, in which numerous studies dealing with true bugs have appeared up to now $[6,7,8,9$, $26,50,63]$. In addition to this series there are also many works providing data on the heteropteran fauna of certain areas of Hungary [1, 17, 22, 23, 24, 25, 42, 43, 47, 48, 49, $51,52,65,67,68]$. The true bugs occurring in Bakony and Mátra mountains were investigated and the data were published mainly by the researchers of the Natural History Museum of Bakony (Zirc) and the Mátra Museum (Gyöngyös) [18, 19, 20, 21, $33,34,35,36]$.

Recently Kondorosy [46] has compiled the most complete checklist of the Hungarian bug fauna.

As a summary, each of the above-mentioned works elaborates a taxonomical group of the true bugs occurring in a geographical area. If the subjects of the examination are the bugs inhabiting a certain habitat, so this is usually the water and/or the water surface. In the Hungarian literature, no publication discussing the Heteroptera inhabiting the ground-level is known. Also, in the international literature, data on the species living on the ground can be found only very sporadically, mostly as parts of great, comprehensive works discussing the soil-inhabiting animals, e.g. [27]. 


\section{Materials and methods}

\section{The material examined}

The investigations were carried out on the rich ground-living animal material collected by the staff of the Department of Systematic Zoology and Ecology of Eötvös Loránd University under the guidance of the late Dr. I. Loksa between 1953-1974. The material preserved in vials of $70 \%$ methyl alcohol was extracted from different substrata with Berlese funnels. All of the heteropteran specimens of Loksa's collection have been sorted and identified.

Altogether 3657 samples taken in all regions of Hungary have been examined. Table 1 contains the list of the localities where heteropteran specimens have been collected, and their UTM codes. The localities are also shown in Fig. 1.

\section{Species identification and nomenclature}

The species have been identified by D. Rédei. For the identification of adults, the following works were used: Dipsocoromorpha, Aradidae: [62]; Nepomorpha: [60]; Gerromorpha, Leptopodomorpha, Nabidae, Reduviidae: [14]; Tingidae: [54]; Miridae: [69, 70, 71, 72, 73, 74]; Microphysidae: [53]; Lygaeidae sensu lato: [55, 56, 57]; Coreidae, Alydidae, Rhopalidae, Stenocephalidae, Pyrrhocoridae, Berytidae, Piesmatidae: [64]; Pentatomoidea: [44].

The larvae, apart from some exceptions, have been identified only at family level using Vásárhelyi’s key [66]. Some elder larvae have been identified at subfamily, genus or species level using the works mentioned above as well as Benedek's key [15].

The classification and name of species are given according to the Catalogue of Aukema and Rieger [2, 3, 4, 5]. In case of taxa, which are not treated in this series, the nomenclature of the works used for identification are followed. To classify the Lygaeidae sensu lato taxa Henry's work [37] was followed.

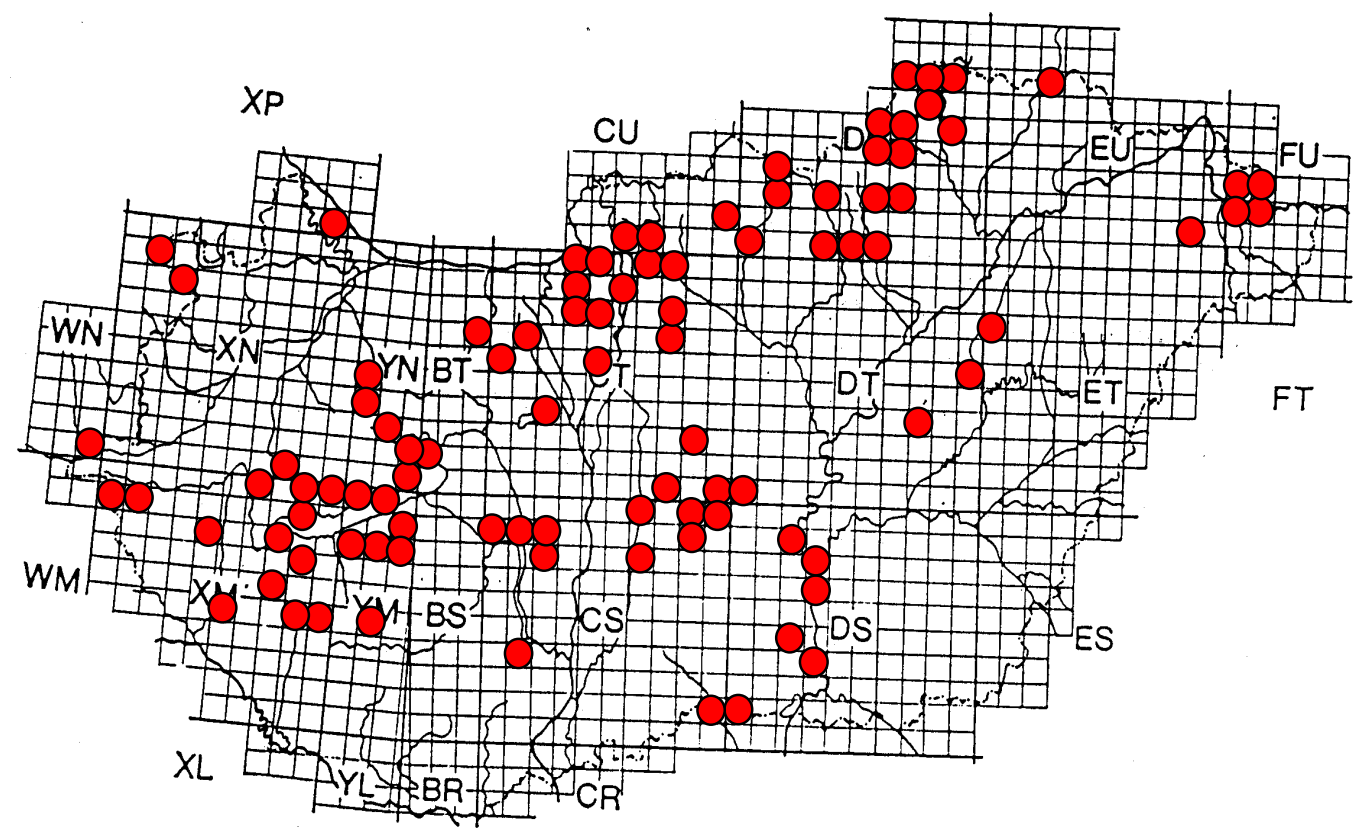

Figure 1. The localities where heteropteran specimens have been collected. 
Table 1. List of the localities where heteropteran specimens have been collected, and their UTM codes.

\begin{tabular}{|c|c|}
\hline Town / village & UTM \\
\hline 1 Alsópetény & CU60 \\
\hline 2 Alsószentiván & $\mathrm{CS} 28$ \\
\hline 3 Alsószuha & DU65 \\
\hline 4 Andocs & YM27 \\
\hline 5 Ábrahámhegy & XM98 \\
\hline 6 Ágasegyháza & CS88 \\
\hline 7 Ásotthalom & DS01 \\
\hline 8 Ásványráró & XP80 \\
\hline 9 Bajánsenye & XM08 \\
\hline 10 Bak & XM47 \\
\hline 11 Bakonybél & YN03 \\
\hline 12 Baktalórántháza & EU81 \\
\hline 13 Balatonalmádi & BT71 \\
\hline 14 Balatonberény & XM77 \\
\hline 15 Balástya & DS24 \\
\hline 16 Bánd & YN12 \\
\hline 17 Beregdaróc & FU13 \\
\hline 18 Bélapátfalva & DU52 \\
\hline 19 Bódvarákó & DU87 \\
\hline 20 Böhönye & XM84 \\
\hline 21 Budaörs & CT45 \\
\hline 22 Bükkszenterzsébet & DU32 \\
\hline 23 Cece & CS18 \\
\hline 24 Csanytelek & DS36 \\
\hline 25 Csaroda & FU03 \\
\hline 26 Csákvár & СT05 \\
\hline 27 Csongrád & DS37 \\
\hline 28 Csöde & XM18 \\
\hline 29 Csővár & CT79 \\
\hline 30 Dömös & СТ39 \\
\hline 31 Eger & DU50 \\
\hline 32 Egerbakta & DU40 \\
\hline 33 Esztergom & СТ39 \\
\hline 34 Felsőörs & YN21 \\
\hline 35 Fenyőfö & YN04 \\
\hline 36 Fülöpháza & CS89 \\
\hline 37 Gödöllő & CT77 \\
\hline 38 Gulács & FU02 \\
\hline 39 Harka & $\mathrm{XN} 27$ \\
\hline 40 Jákfalva & DU65 \\
\hline 41 Jánd & FU03 \\
\hline 42 Jósvafö & DU67 \\
\hline 43 Kakasd & CS13 \\
\hline 44 Káptalantóti & XM99 \\
\hline 45 Kecskemét & CS99 \\
\hline 46 Kelebia & CS91 \\
\hline 47 Kelemér & DU55 \\
\hline 48 Kenderes & DT73 \\
\hline
\end{tabular}

\begin{tabular}{|c|c|c|}
\hline & Town / village & UTM \\
\hline 49 & Kékkút & XM99 \\
\hline 50 & Kosd & СТ69 \\
\hline 51 & Kövágóörs & XM99 \\
\hline 52 & Kunbaracs & СТ70 \\
\hline 53 & Lajosmizse & СТ90 \\
\hline 54 & Lengyeltóti & YM07 \\
\hline 55 & Lesenceistvánd (Uzsabánya) & XN70 \\
\hline 56 & Lovas & YN20 \\
\hline 57 & Marcali & XM86 \\
\hline 58 & Mátraszőlős & CU91 \\
\hline 59 & Mesztegnyő & XM85 \\
\hline 60 & Mezőszilas & CS08 \\
\hline 61 & Monoszló & YM09 \\
\hline 62 & Nagybajom & XM94 \\
\hline 63 & Nagyiván & DT95 \\
\hline 64 & Nagykanizsa & XM43 \\
\hline 65 & Nagykovácsi & CT47 \\
\hline 66 & Nagykőrös & DT00 \\
\hline 67 & Nagymaros & CT49 \\
\hline 68 & Nemesgulács & XM89 \\
\hline 69 & Nemesvid & XM75 \\
\hline 70 & Nemesvita & XM88 \\
\hline 71 & Nikla & XM96 \\
\hline 72 & Ohat & ET07 \\
\hline 73 & Oroszlány & BT96 \\
\hline 74 & Pásztó & DU00 \\
\hline 75 & Pécel & CT76 \\
\hline 76 & Piliscsaba & СТ37 \\
\hline 77 & Piliscsév & СТ38 \\
\hline 78 & Pilisszentkereszt & CT48 \\
\hline 79 & Pilisszentkereszt (Dobogókő) & CT48 \\
\hline 80 & Pilisszentlászló & CT48 \\
\hline 81 & Pócsmegyer & СТ58 \\
\hline 82 & Pusztaszemes & YM28 \\
\hline 83 & Pusztavacs & CT82 \\
\hline 84 & Putnok & DU54 \\
\hline 85 & Répáshuta & DU62 \\
\hline 86 & Sándorfalva & DS33 \\
\hline 87 & Sajókaza & DU64 \\
\hline 88 & Salgótarján & DU12 \\
\hline 89 & Salgótarján (Somoskőújfalu) & DU13 \\
\hline 90 & Simontornya & CS18 \\
\hline 91 & Sirok & DU30 \\
\hline 92 & Solymár & CT47 \\
\hline 93 & Somogyaszaló & YM14 \\
\hline 94 & Somogytúr & YM17 \\
\hline 95 & Somogyzsitfa & XM75 \\
\hline 96 & Sopron & $\mathrm{XN18}$ \\
\hline
\end{tabular}


Table 1. (continued).

\begin{tabular}{rlc}
\hline & \multicolumn{1}{c}{ Town / village } & UTM \\
\hline 97 & Szabadszállás & CS69 \\
98 & Szár & CT16 \\
99 & Szendrölád & DU85 \\
100 & Szendehely & CU50 \\
101 & Szentbékkálla & XM99 \\
102 & Szentendre & CT58 \\
103 & Szentgotthárd & WN90 \\
104 & Szenyér & XM84 \\
105 & Szigetmonostor & CT58 \\
106 & Szögliget & DU77 \\
107 & Tarpa & FU12 \\
108 & Telkibánya & EU27 \\
109 & Tihany & YM19 \\
\hline
\end{tabular}

\begin{tabular}{llc}
\hline & \multicolumn{1}{c}{ Town / village } & UTM \\
\hline 110 & Tiszaalpár & DS28 \\
111 & Tornakápolna & DU76 \\
112 & Vajta & CS27 \\
113 & Vámosatya & FU03 \\
114 & Velence & CT23 \\
115 Vindornyaszőlös & XM69 \\
\hline 116 Badacsony & $*$ \\
117 Bakony & $*$ \\
118 Cserhát & $*$ \\
119 Karancs & $*$ \\
120 Naszály & $*$ \\
121 Putnoki-dombság (Hills) & $*$ \\
122 Somló & $*$ \\
\hline
\end{tabular}

*The exact collecting place is unknown because Loksa recorded only the name of the region or geographic area.

\section{Results}

\section{Faunistical results: an annotated checklist}

A total number of 5060 heteropteran specimens have been found in the examined material. The specimens represent 157 species belonging to 31 families. The majority $(57.63 \%)$ of the extracted specimens are larvae (Table 2$)$.

Table 2. The distribution of specimens examined.

\begin{tabular}{lc}
\hline \multicolumn{1}{c}{ Level of identification } & $\begin{array}{c}\text { Number of } \\
\text { specimens }\end{array}$ \\
\hline adults identified at species level & 2096 \\
larvae identified at species level & 118 \\
adults identified to family or genus level (mostly defected) & 48 \\
larvae identified to family or genus level & 2708 \\
unidentified larvae $\left(1^{\text {st }}\right.$ and $2^{\text {nd }}$ instars) & 90 \\
\hline altogether & 5060 \\
\hline
\end{tabular}

In the list below, the order of families follows the Palaearctic catalogue of Aukema $\&$ Rieger $[2,3,4,5]$. The name of species or subspecies is followed by the recorded collecting localities marked by Arabic numbers in italics (see Table 1), then by Roman numerals referring to the month in which specimens were collected, and finally the enumeration of the examined material. When giving the time of samplings, duration (V-VII. e.g.) is only indicated when we have data from each month of the period.

\section{CERATOCOMBIDAE}

Ceratocombus (Ceratocombus) coleoptratus (Zetterstedt, 1819). 7, 12, 15, 23, 24, 25, 27, 32, 33, 46,

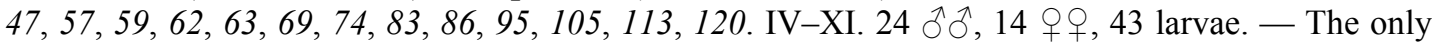
species of the family known from Hungary. A very limited number of specimens have been collected in the country before Loksa, who extracted large series of this species in some places. Based on this material, the species' distribution, coenology, wing polymorphism and phenology in Hungary were discussed by the authors [58]. 


\section{DIPSOCORIDAE}

The family is represented by 3 species in Hungary. A very limited number of specimens of each species have been collected in the country before. Only two of them have been captured by Loksa. The distribution, coenology, wing polymorphism and phenology of the species in Hungary based on Loksa's materials were discussed by the authors [58].

Cryptostemma (Pachycoleus) pusillimum (J. Sahlberg, 1870). 7, 9, 15, 27, 33, 36, 40, 47, 49, 53, 56, $62,75,77,100,101,103,113,118,120,121$. III, V-VII, IX-XI. $24 \partial^{\lambda}, 50$ 오우, 56 larvae. - It is distributed all over the country. In some places a great number of it have been extracted with Berlese funnel.

Cryptostemma (Pachycoleus) waltli (Fieber, 1860). 59. IX. 18 $\hat{\partial}$, 15 우, 14 larvae. - It seems to be rare in Hungary. Several specimens have been extracted with Berlese funnel from the same locality.

PleidAe

Plea minutissima minutissima Leach, 1817. 46. XI. 1 औ. - A single, probably overwintering specimen has been extracted from wet debris collected at waterside.

\section{HEBRIDAE}

Hebrus (Hebrus) pusillus pusillus (Fallén, 1807). 8, 40, 50, 51. IV, VI, X, XI. 5 ๙, 5 ㅇ․ According to literature data, it occurs sporadically in Hungary, frequent at some places [14]. However, Loksa has captured only a few specimens. Most of the specimens have been collected around waters, and one specimen has been found also in moss far from waters.

Hebrus (Hebrusella) ruficeps Thomson, 1871. 9, 15, 25, 26, 27, 28, 32, 33, 35, 36, 40, 47, 49, 50, 51,

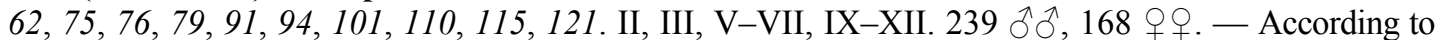
literature data, it occurs sporadically in Hungary, not frequent [14]. However, Loksa has extracted a great number of it. Specimens have been collected mainly at waterside places, and in other habitats, too.

\section{HYDROMETRIDAE}

Hydrometra gracilenta Horváth, 1899. 5. X. 1 ․ - - Quite rare in Hungary. A single specimen has been extracted from wet debris collected at waterside.

\section{VELIIDAE}

Microvelia reticulata (Burmeister, 1835). 51, 61, 115. X, XII. 14 ㅅํ, 3 우우, 2 larvae. - Each of the specimens has been collected at waterside places.

GERRIDAE

Gerris (Gerris) thoracicus Schummel, 1832. 1. XI. 1 ․ - - A single, probably overwintering female has been extracted from a sample collected at shore.

Gerris (Gerris) argentatus Schummel, 1832. 8, 59. IV, IX. 1 ô, 1 \%. — Specimens have been extracted from a sample collected at waterside.

\section{SALDIDAE}

Chartoscirta cincta cincta (Herrich-Schäffer, 1841). 14, 47. VIII, XI. 2 ๙ $\sigma^{\text {. }}$

Chartoscirta elegantula (Fallén, 1807). 5, 47. III, X. 1 ○, 1 q. - For a long time it was known in Hungary only from Bátorliget [14], but lately it has been recorded from several places (Bugac, Tabdi [8], Budapest [43]). It seems to be rare everywhere in the country.

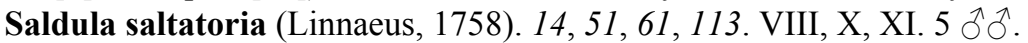

\section{TINGIDAE}

Campylosteria verna (Fallén, 1826). 13, 16, 18, 25, 26, 33, 37, 38, 42, 50, 58, 67, 68, 76, 78, 79, 80, 85, $98,100,109,112,113,117$. II-VII, IX-XII. 60 के $\sigma^{\lambda}, 101$ 우. - Distributed everywhere in Hungary. It has been found mainly in mountainous regions.

Campylosteira orientalis Horváth, 1881. 24. IX. 1 ㅇ․ - Very rare, its life habits are practically unknown. It is mentioned in the literature as a species occurring in Hungary (f. n.: Tokaj [38], 
Budapest [62]; f. suspecta Horváth, 1892: Szentendre [40]). However, no voucher specimen is known [62]. Therefore, the only specimen (standing near to the form suspecta) collected by Loksa is regarded as the first specimen representing the species in Hungary. Data of collection: Csanytelek, 5. IX. 1972, 1 brachypterous + , leg. Loksa.

Acalypta carinata (Panzer, 1806). 59, 64, 85, 100, 108, 113. V-VII, IX. 26 ふぇ, 40 우. — For a long time it was recorded only from Zirc [39], but without voucher specimen. Later it was found at Bátorliget [61], and lately several specimens of it have been captured in this place with pitfall trap and by sifting [68]. Also the majority of the specimens collected by Loksa have been found in the territory to the east of the river Tisza (Vámosatya). It seems to be rare in Hungary, locally more frequent.

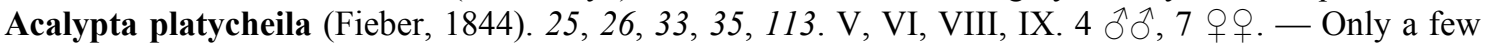
specimens have been found in Hungary hitherto [7, 61, 62, 68]. Probably it occurs sporadically all over the country but it seems to be rare everywhere.

Acalypta nigrina (Fallén, 1807). 18. V, VII. 5 우. - Only a single specimen has been recorded from Hungary hitherto (Hegyalja [61, 62]). Loksa has also extracted some specimens from moss. One of the rarest Acalypta species in Hungary.

Acalypta marginata (Wolff, 1804). 18, 19, 23, 35, 60, 75, 78, 81, 85, 88, 89, 107, 108, 109, 113, 119. IV-VII. $18 \hat{\jmath} \hat{\jmath}, 36$ 우. - Not frequent in Hungary but occurs sporadically all over the country. Several specimens have been extracted by Loksa.

Acalypta parvula (Fallén, 1807). 10, 13, 30, 33, 39, 44, 50, 58, 67, 68, 70, 76, 78, 79, 80, 85, 92, 96,

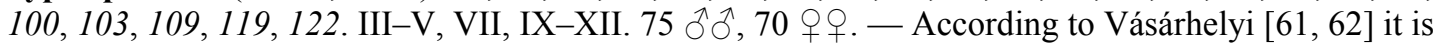
rare in Hungary and known only from a few localities. However, Loksa has extracted numerous specimens of this species. It seems to occur everywhere in the country and to be frequent.

Acalypta gracilis (Fieber, 1844). 19, 52, 81, 83, 109. V-VII, X. $3 \hat{\jmath} \hat{\jmath}, 8$ 우. - Several localities are known from Hungary, mainly on the Great Hungarian Plain (Alföld) [7, 8, 62]. It seems to be quite rare in the country.

Acalypta musci (Schrank, 1781). 3, 11, 18, 19, 30, 31, 33, 42, 47, 50, 65, 70, 74, 78, 79, 80, 84, 85, 96, 99, 100, 102, 106, 110, 111, 117. II-XII. 201 추, 155 우, 1 adult (damaged specimen). — Frequent in Hungary. Most of the specimens captured by Loksa have been collected in the mountains Bükk. In some places, large series of this species have been extracted.

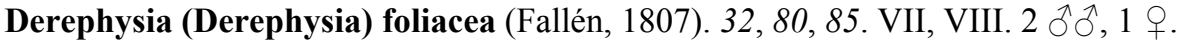

Stephanitis pyri (Fabricius, 1822). 113. XI. 1 ㅇ.

Lasiacantha capucina capucina (Germar, 1836). 9, 21, 62, 65, 77, 112. III, X-XII. 3 ๙ึ, 5 우.

Tingis (Tingis) cardui (Linnaeus, 1758). 117. ?. 1 $\hat{\sigma}, 1$ ․

Tingis (Tropidocheila) geniculata (Fieber, 1844). 70. ?. 1 q.

Tingis (Tropidocheila) reticulata Herrich-Schäffer, 1835. 79. X. 1 ․

Catoplatus carthusianus (Goeze, 1788). 21, 68. III. 2 우.

Copium teucrii teucrii (Host, 1788). ?. ?. 1 ․ - This Mediterranean species is quite rare in Hungary, and known only from the environs of Budapest, the mountains Mátra [61, 62] and the area of the Aggtelek National Park [26]. The data on the single species collected by Loksa are lost.

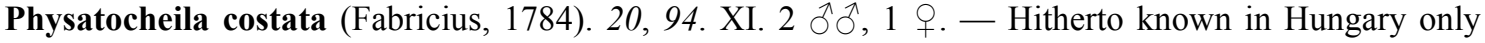
from few places (Göd, Kapuvár, Mosonmagyaróvár, Parád) [61, 62].

Oncochila scapularis (Fabricius, 1794). 53. XI. 1 q.

Dictyla humuli (Fabricius, 1794). 25. IX. 1 ๙ .

Dictyla rotundata (Herrich-Schäffer, 1835). 42. IX. 1 ऽ.

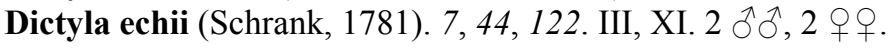

Agramma (Agramma) confusum (Puton, 1879). 7, 36, 53, 60, 62, 90. V, IX, XI. 5 ๙ึ่, 6 우.

Agramma (Agramma) minutum Horváth, 1874. 39, 52, 53. X, XI. 3 q $q$.

\section{MICROPHYSIDAE}

The family is represented by 5 species in Hungary [46]. A very limited number of specimens of each species have been collected in the country before because of their minute size and cryptic life habits.

Loricula pselaphiformis Curtis, 1833. 78. VI. 1 §. - Recorded only from Eger [62], Bazsi [34] and Bátorliget [68] so far.

Loricula ruficeps (Reuter, 1844). 26, 37, 85, 113. V-VIII. 4 $\widehat{\jmath}, 16$ 우. — Very rare in Hungary, only one place of occurrence has been recorded in the country up to now (Tahi [62]). However, in one occasion Loksa extracted 11 female specimens from the same sample. 
Loricula elegantula (Bärensprung, 1858). 50. VI. $1 \hat{\jmath}, 5$ 우. - Rare in Hungary, only some specimens have been collected so far, mainly in the highlands [62].

Myrmedobia exilis (Fallén, 1807). 12, 42, 55, 62, 69, 104, 115. VI, VIII, IX. 11 우. — Recorded only from Budapest [62], Bátorliget [68] and Darány [48] so far.

\section{MIRIDAE}

Monalocoris (Monalocoris) filicis (Linnaeus, 1758). 47. IX. 1 9. - Boreo-montaneous species, rare in Hungary.

Deraeocoris (Knightocapsus) lutescens (Schilling, 1837). 3, 109. XI. 1 ఠ, 1 +

Lygus rugulipennis Poppius, 1911. 5, 87, 113. X, XI. 3 $ぇ,, 2$ 우.

Lygus pratensis (Linnaeus, 1758). 44, 80. III, XII. 2 q.

Lygus gemellatus gemellatus (Herrich-Schäffer, 1835). 47, 52. XI. 2 우.

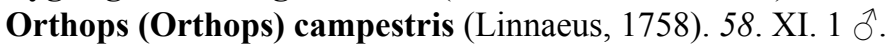

Orthops (Orthops) kalmii (Linnaeus, 1758). 58. XI. 1 $\lesssim$.

Stenodema (Brachystira) calcarata (Fallén, 1807). 8. IV. 1 ㅇ.

Halticus apterus apterus (Linnaeus, 1758). 74. VI. 1 $\lesssim$.

Tytthus pygmaeus (Zetterstedt, 1838). 61. X. 1 ㅇ. - Can be found in humid meadows, bogs, etc., probably mainly at the ground-level. Although its occurrence in Hungary has only been proved recently [68], the species does not seem to be rare in suitable places.

\section{NABIDAE}

Alloeorhynchus (Alloeorhynchus) flavipes (Fieber, 1836). 37, 100. IV, VII. 1 +, 1 larva. - Rare in Hungary, known mainly from lowlands.

Himacerus (Aptus) mirmicoides (O. Costa, 1834). 5, 18, 44. II, III, X. $2 \widehat{\diamond}, 2$ 우.

Nabis (Nabis) rugosus (Linnaeus, 1758). 55, 58. VIII, XI. 1 ô, 1 ㅇ.

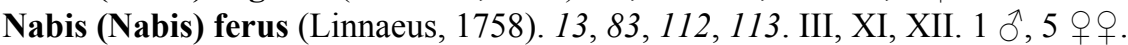

Nabis (Nabis) pseudoferus pseudoferus Remane, 1949 $ぇ .18,20,58,79,117$. III, X, XI. 5 $ぇ$.

Nabis (Nabis) pseudoferus pseudoferus Remane, 1949 and N. (N.) punctatus punctatus A. Costa, 1847 우. 5, 43, 47, 61, 113. IX-XI. 5 우. - Because of the very difficult distinguishing, the females of this two species have not been identified.

\section{REDUVIIDAE}

Phymata crassipes (Fabricius, 1775). 81. VI. 1 larva. - Not rare in Hungary, distributed mainly in the mountainous regions.

\section{ARADIDAE}

Aradus cinnamomeus Panzer, 1806. 112. XII. 1 o, 1 larva. - According to the literature [62], the species overwinters as adult. However, a $5^{\text {th }}$ instar larva has also been extracted from a sample taken in December (03. XII). This suggests that occasionally elder larvae can also overwinter.

Aradus distinctus Fieber, 1860. 37, 68. XII. 2 $ぇ$.

Aneurus (Aneurodes) avenius (Dufour, 1833). 113. XI. 1 §.

Aneurus (Aneurus) laevis (Fabricius, 1775). ?. X. 1 $\delta$.

PIESMATIDAE

Piesma capitatum (Wolff, 1804). 7, 19, 112. XI, XII. $4 \hat{\jmath}$

Piesma maculatum (Laporte, 1833). 25, 29, 38, 43, 48, 63, 72, 74, 93, 104, 113. IV, VI, IX, XI. 19 ఏో 18 우.

Parapiesma quadratum (Fieber, 1844). 45, 53. X, XI. 3 q $q$.

Parapiesma silenes (Horváth, 1888). 45, 122. X, XI. 1 §, 1 ๆ. - Far more rare than the species before, known mainly from the Great Hungarian Plain.

Parapiesma salsolae (Becker, 1867). 7, 45, 83, 112. X-XII. 5 ふぇં, 3 우.

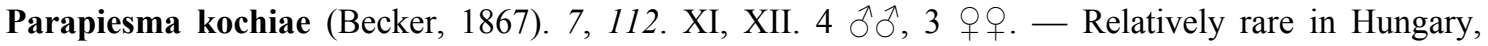
known mostly from the territory between the rivers Danube and the Tisza. 
BERYTIDAE

Berytinus (Berytinus) minor minor (Herrich-Schäffer, 1835). 74. VI. 1 ㅇ.

Berytinus (Lizinus) signoreti (Fieber, 1859). 58. XI. 1 +. - Rare in Hungary, known only from the environs of Budapest, the Bakony Mountains and Velem [64]. Its life habits and phenology are unknown but its occurrence in late autumn suggests that it overwinters as adult.

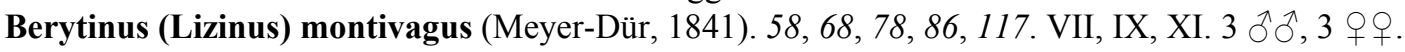

Berytinus (Lizinus) geniculatus (Horváth, 1885). 109. ?. 1 \%. - Relatively rare in Hungary, known mostly from the lowlands.

\section{LYGAEIDAE}

Horvathiolus superbus (Pollich, 1781). 18. V. 1 त. - Rare in Hungary, only a few places of occurrence are known.

Lygaeosoma sardeum sardeum Spinola, 1837. 70. ?. 1 ㅇ.

Nysius senecionis senecionis (Schilling, 1829). 29, 83. XI. 1 ô, 1 q.

\section{CYMIDAE}

Cymus glandicolor Hahn, 1832. 46. XI. 1 กิ.

Cymus aurescens Distant, 1833. 3, 62. XI. 3 ㅇ․ - - The rarest species of the genus in Hungary, known mainly from the highlands.

\section{BLISSIDAE}

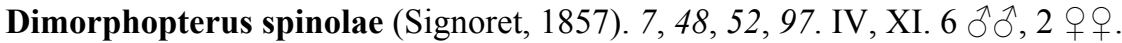

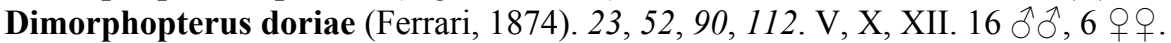

\section{GEOCORIDAE}

Geocoris (Geocoris) ater (Fabricius, 1787). 112. XII. 1 $\hat{\rho}, 1$ ㅇ.

HETEROGASTRIDAE

Platyplax salviae (Schilling, 1829). 44. ?. 1 §.

\section{OXYCARENIDAE}

Oxycarenus (Oxycarenus) modestus (Fallén, 1829). 94. XI. 1 đ.

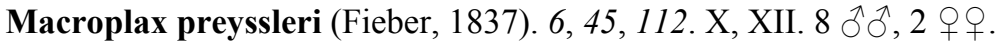

Macroplax fasciata fasciata (Herrich-Schäffer, 1835). 50. X. 1 ते.

Metopoplax origani (Kolenati, 1845). 45, 48, 76, 112. IV, X-XII. 5 ठิ $\widehat{\partial}, 1$ ㅇ.

Camptotelus lineolatus lineolatus (Schilling, 1829). 109. ?. 1 خे.

Tropidophlebia costalis (Herrich-Schäffer, 1850). 114. V. 1 o, 1 ․ - Rare in Hungary, has been found at Barcs, Bugac, Fülöpháza, Nagyszénás and the environs of Budapest up to now [45].

\section{RHYPAROCHROMIDAE}

Plinthisus (Plinthisus) brevipennis (Latreille, 1807). 37, 47, 50, 55, 83, 85, 109. III-VIII, X-XII. 14 충, 13 우우.

Plinthisus (Plinthisus) longicollis Fieber, 1861. 68, 70, 112. IX, XII. $1 \curvearrowright, 5$ $\uparrow$. - It occurs sporadically throughout the country but is quite rare.

Plinthisus (Plinthisomus) pusillus (Scholtz, 1847). 2, 23, 44, 54, 55, 58, 65, 66, 69, 83, 85, 95, 97, 109, 112. V, VII-IX, XI, XII. $12 \hat{\jmath}, 17 q$ q

Stygnocoris sabulosus (Schilling, 1829). 33, 55, 78, 83, 117. VI-VIII, X. 2 丸ึ $0^{4} 4$ 웅.

Stygnocoris pygmaeus (R. F. Sahlberg, 1848). 19, 26, 50, 55, 83. VII, VIII, XI. 5 §ð, 3 우․ According to the literature [56], the species overwinters in the egg stage. However, an adult has also been collected in late November (29. XI).

Acompus pallipes (Herrich-Schäffer, 1834). 86. IX. 1 q.

Drymus (Sylvadrymus) sylvaticus (Fabricius, 1775). 9, 25, 68, 82. VII, IX, X. 2 ○ึ, 2 웅․ 
Drymus (Sylvadrymus) ryeii Douglas \& Scott, 1865. 26, 44, 61, 64, 77, 115. V, VI, VIII, X-XII. 6 ふぇ, 4 우우.

Drymus (Sylvadrymus) brunneus brunneus (R. F. Sahlberg, 1848). 25, 59, 62, 64, 88. VI, IX, XI. 10 ふ઼่, 6 우.

Eremocoris podagricus (Fabricius, 1775). 1, 13, 34, 43, 44, 49, 83, 96. III, V, X, XI. 7 ふぇ, 5 우.

Eremocoris plebejus (Fallén, 1807). 9. X. 1 1 . - Rare in Hungary, distributed mainly in the mountainous regions.

Scolopostethus thomsoni Reuter, 1875. 47, 96, 113. V, IX, XI. 1 ㄱ, 4 우우.

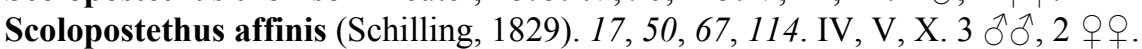

Scolopostethus puberulus Horváth, 1887. 33, 37. X. 1 ๙ , 1 \%. - According to literature data [45], it is very rare in Hungary.

Scolopostethus pilosus pilosus Reuter, 1874. 12, 47, 85. V, IX, XI. 2 ठे

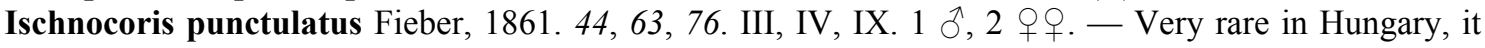
has been collected only at two localities (Budapest, Sátoraljaújhely) so far [45].

Ischnocoris hemipterus (Schilling, 1829). 44, 70, 92. X. 4 के $\sigma^{\lambda}, 1$ 오.

Tropistethus holosericus (Scholtz, 1846). 18, 37, 43, 44, 63, 68, 69, 70, 87, 109, 113. III, IV, VIII, IX, XI. $13 \precsim \hat{\jmath}, 6$ 우우.

Pionosomus opacellus Horváth, 1895. 112. XII. 1 $\delta, 2$ 우. - A lowland species, known exclusively from the Great Hungarian Plain (Alföld).

Emblethis verbasci (Fabricius, 1803). 97, 117. XI. 1 ๙े, 1 ㅇ.

Emblethis griseus (Wolff, 1802). 37. XII. 1 ๙ิ, 1 ㅇ.

Emblethis denticollis Horváth, 1878. 45. X. 1 ๙ิ, 1 ㅇ.

Emblethis ciliatus Horváth, 1875. 112. XII. $3 \hat{\jmath} \widehat{\jmath}$.

Trapezonotus (Trapezonotus) arenarius arenarius (Linnaeus, 1758). 5, 44, 45, 50, 51, 112. X, XII. 5 ิेग, 1 ㅇ.

Trapezonotus (Trapezonotus) dispar Stål, 1872. 85. X. 1 ఠ.

Aphanus rolandri (Linnaeus, 1758). 46. XI. 1 厄.

Megalonotus chiragra (Fabricius, 1794). 41, 85, 122. II, VIII, IX. 1 $\uparrow, 3$ ㅇq.

Megalonotus sabulicola (Thomson, 1870). 1, 5, 37, 50, 62, 68, 100, 109, 117. III, IX-XI. 4 §ð, 9 우.

Megalonotus antennatus (Schilling, 1829). 78, 100. III, X. 1 $\curvearrowright, 1$ q. - Quite rare in Hungary, more frequent in the highlands.

Megalonotus praetextatus (Herrich-Schäffer, 1835). 83, 112. XI, XII. 2 q q.

Peritrechus geniculatus (Hahn, 1832). 19. XII. 1 స.

Peritrechus gracilicornis Puton, 1877. 7, 15, 25, 45. IX-XI. 4 웅.

Peritrechus nubilus (Fallén, 1807). 44, 83. V, XI. 2 $\widehat{\jmath}$.

Beosus maritimus (Scopoli, 1763). 33, 94. X, XI. 1 ก, 1 ㅇ.

Graptopeltus lynceus (Fabricius, 1775). 19, 117. VIII, X. 4 웅․

Raglius alboacuminatus (Goeze, 1778). 37. X. 1 त.

Rhyparochromus pini (Linnaeus, 1758). 122. XI. 1 q

Rhyparochromus vulgaris (Schilling, 1829). 47, 106. III, VI, IX, XI. 3 $ぇ ึ, 14$ q $q$.

Pachybrachius fracticollis (Schilling, 1829). 9, 12, 28, 95, 103. VIII-X. $1 \hat{\jmath}, 4$ 우우.

\section{PYRRHOCORIDAE}

Pyrrhocoris apterus (Linnaeus, 1758). 16. V. 1 \%.

Pyrrhocoris marginatus (Kolenati, 1845). 50. X. 1 q.

\section{COREIDAE}

Coreus marginatus (Linnaeus, 1758). 94. XI. 1 ․

Spathocera obscura (Germar, 1842). 52, 112. X, XII. $1 \hat{\jmath}, 1$ ․ - Rare in Hungary, known only from the Great Hungarian Plain.

Bathysolen nubilus (Fallén, 1807). 68, 117. V. 1 ก, 1 ․ - Quite rare in Hungary.

Coriomeris denticulatus (Scopoli, 1763). 70. IV. 2 우.

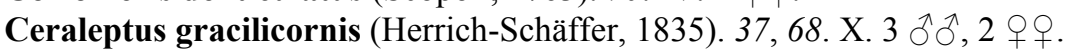




\section{RHOPALIDAE}

Rhopalus (Rhopalus) subrufus (Gmelin, 1788). 62. XI. 1 ๙.

Brachycarenus tigrinus (Schilling, 1817). 50, 58, 109. III, XI. 2 ๙ $0^{\lambda}, 2$ 우․

\section{CYDNIDAE}

Microporus nigritus (Fabricius, 1794). 37, 68. V, XII. 1 ภ, 1 ㅇ.

Cydnus aterrimus (Forster, 1771). 44. III. 1 th.

Legnotus limbosus (Geoffroy, 1785). 18, 19, 29, 37, 44, 57, 59, 62, 68, 70, 73, 79, 80, 83, 95, 106, 109, 122. III-XII. $35 \partial^{\lambda} \hat{O}^{\lambda}, 40$ 웅.

Tritomegas bicolor (Linnaeus, 1758). 57, 71. VII. 1 ก , 1 ㅇ․

Adomerus biguttatus (Linnaeus, 1758), 103. X. 1 กิ.

\section{THYREOCORIDAE}

Thyreocoris scarabaeoides (Linnaeus, 1758). 4, 22, 43, 54, 59, 62, 68, 79. VI, VII, IX-XI. $5 \hat{\jmath} \widehat{\partial}, 3$ 우우. - Occurs sporadically in Hungary, nowhere frequent.

\section{SCUTELLERIDAE}

Eurygaster austriaca (Schrank, 1776). 29, 37, 68, 112, 113, 122. VII, XI, XII. 3 ๙

Eurygaster maura (Linnaeus, 1758). 47, 68, 70, 76, 122. IV, IX-XI. $3 \hat{\delta}$ ㄱ, 3 우우.

Eurygaster testudinaria (Geoffroy, 1758). 47, 50, 68, 93, 116, 122. III, XI. $2 \hat{\jmath} \hat{\partial}, 8$ 우우.

\section{Pentatomidae}

Podops inuncta (Fabricius, 1775). 1. XI. 1

Sciocoris (Sciocoris) cursitans (Linnaeus, 1758). 44, 117. III, V. 2 ๙ 0 , 2 우우.

Sciocoris (Aposciocoris) homalonotus Fieber, 1851. 44, 50, 68, 70, 78, 79, 80, 109, 116. III, V, VI, X.

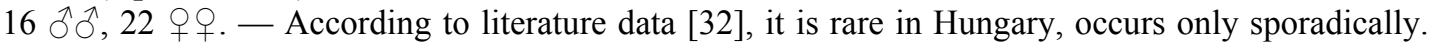
However, Loksa has extracted a great number of it.

Sciocoris (Aposciocoris) microphthalmus Flor, 1860. 50. VI. 1 oे.

Dyroderes umbraculatus (Fabricius, 1775). 44. III. 1 ㅇ.

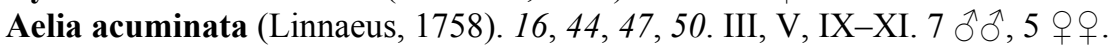

Aelia rostrata Boheman, 1852. 44. III. 1 .

Neottiglossa leporina (Herrich-Schäffer, 1830). 52. XI. 1 ๙ .

Eusarcoris aeneus (Scopoli, 1763). 3. XI. 1 ㅇ.

Dolycoris baccarum (Linnaeus, 1758). 117. ?. 1 กิ.

Palomena prasina (Linnaeus, 1758). 70. ?. 1 q.

Eurydema ventrale Kolenati, 1846. 122. XI. 1 خิ.

Eurydema oleraceum (Linnaeus, 1758). 11, 116. III, X. 1 ^ิ, 1 \%.

ACANTHOSOMATIDAE

Elasmucha grisea (Linnaeus, 1758). 96. XI. 1 $\$$. - Quite rare in Hungary.

\section{Species composition}

The number of species and specimens belonging to different families are summarized in Table 3. The ratio of species and specimens belonging to some major groups of Heteroptera are shown in Figs. 2-4. 
Table 3. The number and ratio of the species known from Hungary and identified from Loksa's materials, and the ratio of the number of the collected specimens $(N=$ number, $\%=$ percentage).

\begin{tabular}{|c|c|c|c|c|c|c|c|}
\hline \multirow[t]{2}{*}{ Family } & \multicolumn{2}{|c|}{$\begin{array}{c}\text { Species known from } \\
\text { Hungary* }\end{array}$} & \multicolumn{2}{|c|}{$\begin{array}{c}\text { Identified species found } \\
\text { in Loksa's materials }\end{array}$} & \multirow{2}{*}{$\begin{array}{c}\left(\frac{N(1)}{N(2)}\right) \\
\%\end{array}$} & \multicolumn{2}{|c|}{$\begin{array}{l}\text { Adult specimens found } \\
\text { in Loksa's materials }\end{array}$} \\
\hline & $N(1)$ & $\%$ & $N(2)$ & $\%$ & & $N$ & $\%$ \\
\hline Ceratocombidae & 1 & 0.12 & 1 & 0.64 & $* *$ & 38 & 1.81 \\
\hline Dipsocoridae & 3 & 0.36 & 2 & 1.27 & $* *$ & 107 & 5.10 \\
\hline Nepidae & 2 & 0.24 & - & - & - & - & - \\
\hline Corixidae & 23 & 2.78 & - & - & - & - & - \\
\hline Naucoridae & 1 & 0.12 & - & - & - & - & - \\
\hline Aphelocheiridae & 1 & 0.12 & - & - & - & - & - \\
\hline Notonectidae & 5 & 0.61 & - & - & - & - & - \\
\hline Pleidae & 1 & 0.12 & 1 & 0.64 & $* *$ & 1 & 0.05 \\
\hline Mesoveliidae & 2 & 0.24 & - & - & - & - & - \\
\hline Hebridae & 2 & 0.24 & 2 & 1.27 & $* *$ & 417 & 19.90 \\
\hline Hydrometridae & 2 & 0.24 & 1 & 0.64 & $* *$ & 1 & 0.05 \\
\hline Veliidae & 6 & 0.73 & 1 & 0.64 & $* *$ & 17 & 0.81 \\
\hline Gerridae & 9 & 1.09 & 2 & 1.27 & $* *$ & 3 & 0.14 \\
\hline Saldidae & 18 & 2.18 & 3 & 1.91 & 16.67 & 9 & 0.43 \\
\hline Leptopodidae & 1 & 0.12 & - & - & - & - & - \\
\hline Tingidae & 64 & 7.75 & 24 & 15.29 & 37.50 & 854 & 40.74 \\
\hline Microphysidae & 5 & 0.61 & 4 & 2.55 & $* *$ & 38 & 1.81 \\
\hline Miridae & 275 & 33.29 & 10 & 6.37 & 3.64 & 17 & 0.81 \\
\hline Nabidae & 16 & 1.94 & 5 & 3.18 & 31.25 & 18 & 0.86 \\
\hline Anthocoridae & 31 & 3.75 & - & - & - & - & - \\
\hline Cimicidae & 3 & 0.36 & - & - & - & - & - \\
\hline Reduviidae & 20 & 2.42 & 1 & 0.64 & 5.00 & - & - \\
\hline Aradidae & 22 & 2.66 & 4 & 2.55 & 18.18 & 5 & 0.24 \\
\hline Piesmatidae & 7 & 0.85 & 6 & 3.82 & $* *$ & 61 & 2.91 \\
\hline Berytidae & 15 & 1.82 & 4 & 2.55 & 26.67 & 9 & 0.43 \\
\hline Lygaeidae & 24 & 2.91 & 3 & 1.91 & 12.50 & 4 & 0.19 \\
\hline Cymidae & 4 & 0.48 & 2 & 1.27 & $* *$ & 4 & 0.19 \\
\hline Blissidae & 3 & 0.36 & 2 & 1.27 & $* *$ & 30 & 1.43 \\
\hline Geocoridae & 6 & 0.73 & 1 & 0.64 & $* *$ & 2 & 0.10 \\
\hline Artheneidae & 2 & 0.24 & - & - & - & - & - \\
\hline Heterogastridae & 5 & 0.61 & 1 & 0.64 & $* *$ & 1 & 0.05 \\
\hline Oxycarenidae & 10 & 1.21 & 6 & 3.82 & $* *$ & 21 & 1.00 \\
\hline Rhyparochromidae & 77 & 9.32 & 39 & 24.84 & 50.65 & 243 & 11.59 \\
\hline Pyrrhocoridae & 2 & 0.24 & 2 & 1.27 & $* *$ & 2 & 0.10 \\
\hline Stenocephalidae & 3 & 0.36 & - & - & - & - & - \\
\hline Coreidae & 23 & 2.78 & 5 & 3.18 & 21.74 & 12 & 0.57 \\
\hline Alydidae & 3 & 0.36 & - & - & - & - & - \\
\hline Rhopalidae & 17 & 2.06 & 2 & 1.27 & 11.76 & 5 & 0.24 \\
\hline Plataspidae & 2 & 0.24 & - & - & - & - & - \\
\hline Cydnidae & 20 & 2.42 & 5 & 3.18 & 25.00 & 81 & 3.86 \\
\hline Thyreocoridae & 2 & 0.24 & 1 & 0.64 & $* *$ & 8 & 0.38 \\
\hline Scutelleridae & 15 & 1.82 & 3 & 1.91 & 20.00 & 22 & 1.05 \\
\hline Pentatomidae & 66 & 7.99 & 13 & 8.28 & 19.70 & 65 & 3.10 \\
\hline Acanthosomatidae & 7 & 0.85 & 1 & 0.64 & $* *$ & 1 & 0.05 \\
\hline Altogether & 826 & 100.00 & 157 & 100.00 & 19.01 & 2096 & 100.00 \\
\hline
\end{tabular}

*According to Kondorosy [46]. The occurrences of some other species in Hungary have been proved since Kondorosy's checklist. However, for the sake of simplicity we took no notice of these species.

**Percentage is given, for practical reasons, in the case of larger numbers only. 


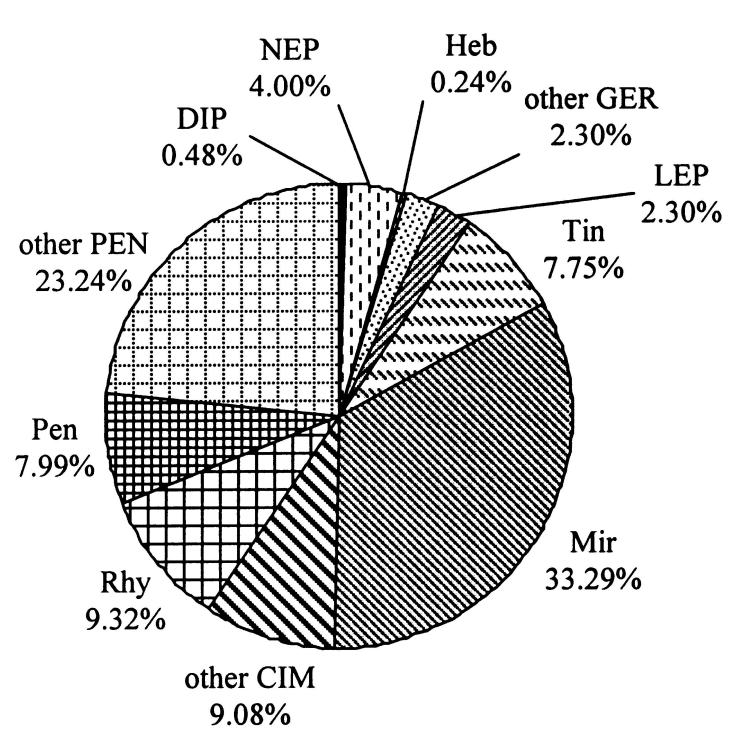

2

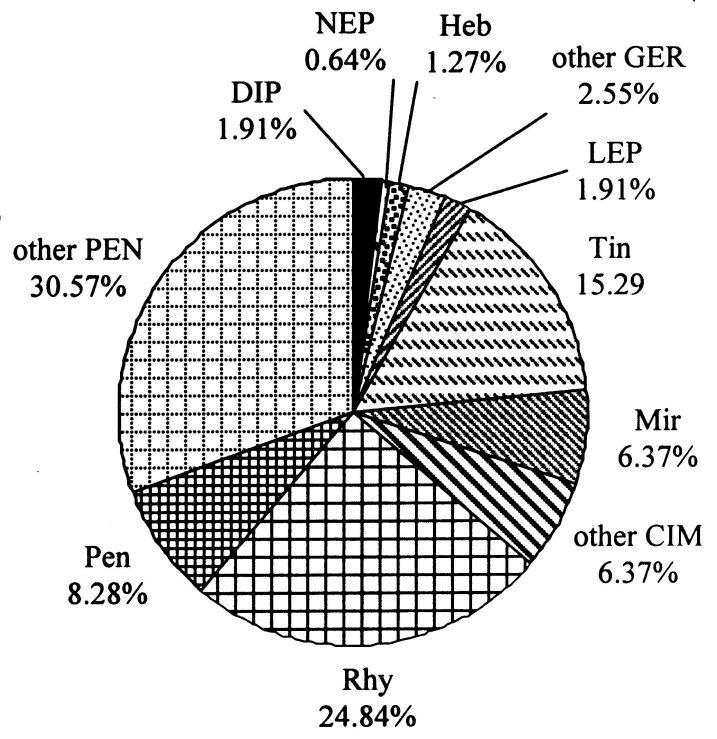

3

Figures 2-3. 2. The ratio of the species known from Hungary belonging to major groups of Heteroptera. 3. The ratio of the species identified from Loksa's materials belonging to major groups of Heteroptera . CIM $=$ Cimicomorpha , DIP $=$ Dipsocoromorpha, GER $=$ Gerromorpha, $\mathrm{LEP}=$ Leptopodomorpha, $\mathrm{NEP}=$ Nepomorpha, $\mathrm{PEN}=$ Pentatomomorpha, $\mathrm{Heb}=$ Hebridae, Mir $=$ Miridae, Pen $=$ Pentatomidae, Rhy $=$ Rhyparochromidae, Tin $=$ Tingidae.

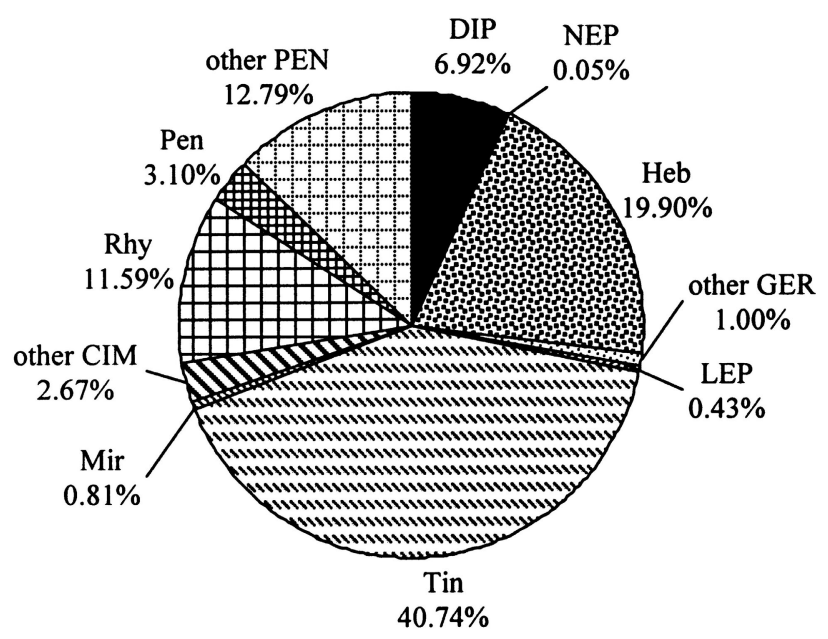

Figure 4. The ratio of the adult specimens identified from Loksa's materials belonging to major groups of Heteroptera. Abbreviations as on Fig. 2 and 3.

\section{Zoogeographical distribution}

Loksa collected samples in all of the great phytogeographical provinces of Hungary (Fig. 5). The numbers of samples taken in the provinces Praeillyricum, Praenoricum and in the Arrabonicum district of province Eupannonicum are considerable lower than that of the other provinces. Therefore, only the samples collected in provinces Eupannonicum (except Arrabonicum), Bakonyicum and Matricum have been compared. 


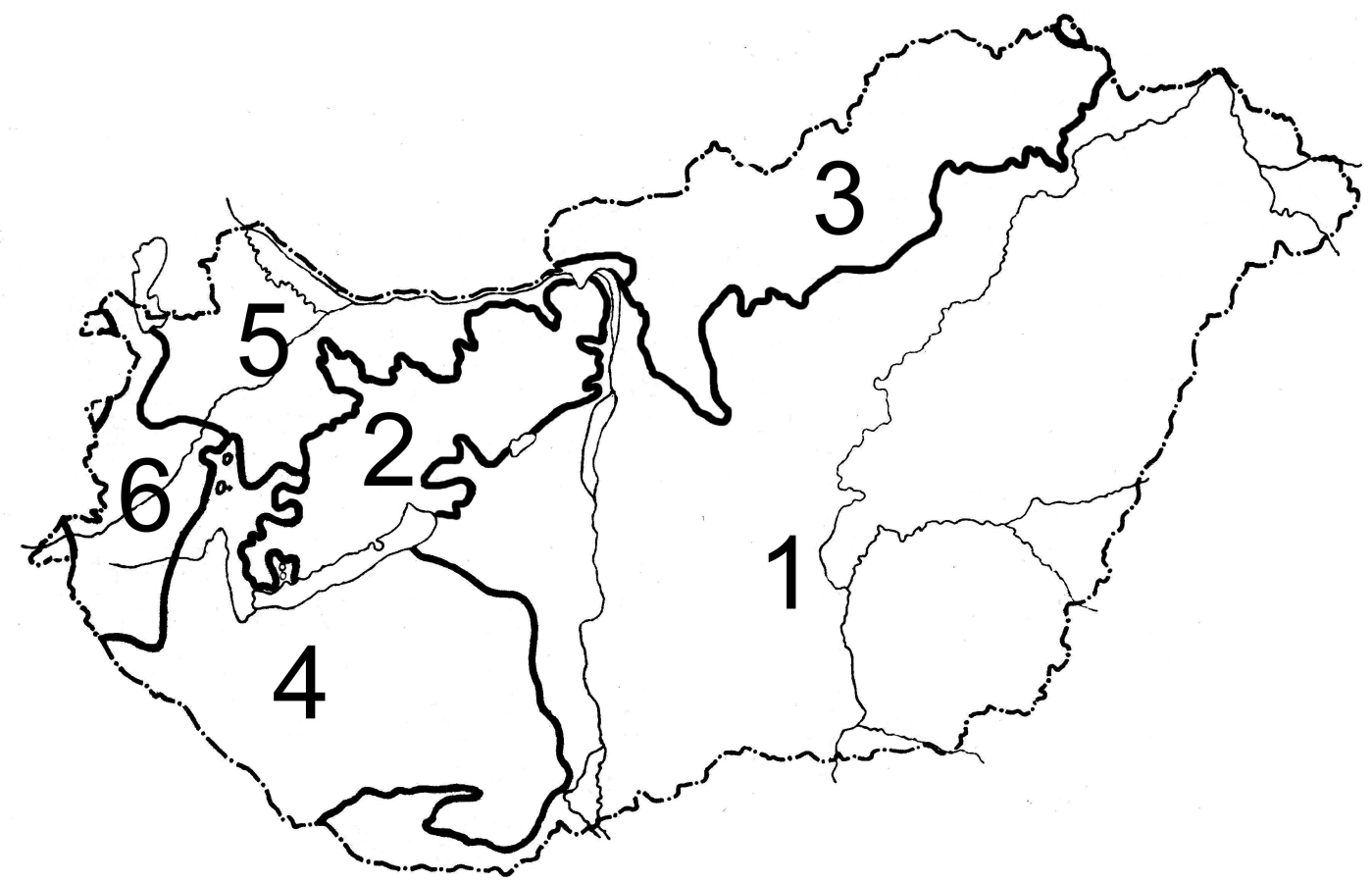

Figure 5. The great phytogeographical provinces of Hungary (after Soó [59], modified). $1=$ Eupannonicum (except Arrabonicum), 2 = Bakonyicum, $3=$ Matricum, $4=$ Praeillyricum, 5 =Eupannonicum (Arrabonicum), $6=$ Praenoricum.

The zoogeographical distribution of heteropteran species and specimens collected in the three most exhaustively investigated provinces in Hungary are shown in Table 4 and 5.

Table 4. The zoogeographical distribution of heteropteran species collected in the three most exhaustively investigated provinces in Hungary $(N=$ number of species, $\%=$ percentage).

\begin{tabular}{|c|c|c|c|c|c|c|c|c|}
\hline \multirow{2}{*}{ Zoogeographical distribution } & \multicolumn{2}{|c|}{ Eupannonicum } & \multicolumn{2}{|c|}{ Bakonyicum } & \multicolumn{2}{|c|}{ Matricum } & \multicolumn{2}{|c|}{ altogether } \\
\hline & $N$ & $\%$ & $N$ & $\%$ & $N$ & $\%$ & $N$ & $\%$ \\
\hline Cosmopolite & - & - & 1 & 1.20 & - & - & 2 & 1.26 \\
\hline Holarctic & 3 & 4.17 & 5 & 6.02 & 4 & 5.26 & 6 & 3.77 \\
\hline Palaearctic (+ Ethiopian) & 12 & 16.67 & 12 & 14.46 & 13 & 17.11 & 30 & 18.87 \\
\hline Eurosiberian (+ Nearctic) & 21 & 29.17 & 17 & 20.48 & 16 & 21.05 & 34 & 21.38 \\
\hline South-Eurosiberian & 5 & 6.94 & 3 & 3.61 & 1 & 1.32 & 7 & 4.40 \\
\hline West-Eurosiberian & 3 & 4.17 & 2 & 2.41 & 3 & 3.95 & 5 & 3.14 \\
\hline West-Palaearctic & 3 & 4.17 & 9 & 10.84 & 10 & 13.16 & 14 & 8.81 \\
\hline European & 7 & 9.72 & 12 & 14.46 & 11 & 14.47 & 18 & 11.32 \\
\hline Euro-Mediterranean (+ Middle-Asian) & 8 & 11.11 & 14 & 16.87 & 10 & 13.16 & 22 & 13.84 \\
\hline Mediterranean (+ Middle-Asian) & 1 & 1.39 & 3 & 3.61 & 3 & 3.95 & 6 & 3.77 \\
\hline Ponto-Mediterranean (+ Middle-Asian) & 5 & 6.94 & 1 & 1.20 & 1 & 1.32 & 7 & 4.40 \\
\hline North-Mediterranean-European (+ Middle-Asian) & 4 & 5.56 & 2 & 2.41 & 2 & 2.63 & 5 & 3.14 \\
\hline Boreo-montaneous & - & - & 2 & 2.41 & 2 & 2.63 & 3 & 1.89 \\
\hline altogether & 72 & 100 & 83 & 100 & 76 & 100 & 159 & 100 \\
\hline
\end{tabular}


Table 5. The zoogeographical distribution of heteropteran specimens collected in the three most exhaustively investigated provinces in Hungary $(N=$ number of specimens, $\%=$ percentage $)$.

\begin{tabular}{|c|c|c|c|c|c|c|}
\hline \multirow{2}{*}{ Zoogeographical distribution } & \multicolumn{2}{|c|}{ Eupannonicum } & \multicolumn{2}{|c|}{ Bakonyicum } & \multicolumn{2}{|c|}{ Matricum } \\
\hline & $N$ & $\%$ & $N$ & $\%$ & $N$ & $\%$ \\
\hline Cosmopolite & - & - & 1 & 0.14 & - & - \\
\hline Holarctic & 7 & 1.43 & 11 & 1.59 & 10 & 1.31 \\
\hline Palaearctic (+ Ethiopian) & 49 & 10.00 & 35 & 5.04 & 19 & 2.48 \\
\hline Eurosiberian (+ Nearctic) & 166 & 33.88 & 83 & 11.96 & 93 & 12.16 \\
\hline South-Eurosiberian & 7 & 1.43 & 5 & 0.72 & 1 & 0.13 \\
\hline West-Eurosiberian & 126 & 25.71 & 112 & 16.14 & 148 & 19.35 \\
\hline West-Palaearctic & 3 & 0.61 & 88 & 12.68 & 99 & 12.94 \\
\hline European & 73 & 14.90 & 243 & 35.01 & 360 & 47.06 \\
\hline Euro-Mediterranean (+ Middle-Asian) & 10 & 2.04 & 66 & 9.51 & 26 & 3.40 \\
\hline Mediterranean (+ Middle-Asian) & 3 & 0.61 & 41 & 5.91 & 3 & 0.39 \\
\hline Ponto-Mediterranean (+ Middle-Asian) & 37 & 7.55 & 1 & 0.14 & 1 & 0.13 \\
\hline North-Mediterranean-European (+ Middle-Asian) & 9 & 1.84 & 6 & 0.86 & 3 & 0.39 \\
\hline Boreo-montaneous & - & - & 2 & 0.29 & 2 & 0.26 \\
\hline altogether & 490 & 100 & 694 & 100 & 765 & 100 \\
\hline
\end{tabular}

\section{Discussion}

As compared to the great effort of collecting, it can be said that the number of heteropteran specimens collected is low. There are only 27 species of which more than 10 adult individuals have been found. Out of these, Ceratocombus coleoptratus, Cryptostemma pusillimum, C. waltli, Acalypta carinata, A. platycheila, Loricula ruficeps, Myrmedobia exilis have been considered to be rare or very rare in Hungary. However, these species have been collected with Berlese funnel in relatively great numbers. Most of them must live mostly at ground-level of suitable plant communities, therefore can not or only accidentally be collected by the usual methods for Heteroptera collecting.

The majority of the species have been collected in very low numbers. Some of these have been also regarded as rare species in Hungary. Such species are Acalypta nigrina, Physatocheila costata, Loricula pselaphiformis, L. elegantula, Tytthus pygmaeus, Acompus pallipes, Bathysolen nubilus, Spathocera obscura and Sciocoris homalonotus. Many of them might to be far more frequent in Hungary as expected. However, they usually escape the heteroperists' attention because they live mostly at ground-level or in related substrata.

No adult individuals belonging to the following families have been collected: Nepidae, Corixidae, Naucoridae, Aphelocheiridae, Notonectidae (aquatic life habits); Mesoveliidae (semi-aquatic life habits); Leptopodidae (usually under stones); Cimicidae (parasitic life habits); Artheneidae, Stenocephalidae, Alydidae, Plataspidae (only few, not characteristic ground-living species in Hungary, it is only accidental that none of them have been collected). The following taxa, more or less rich in species, are represented by only a few species in the material collected: Nepomorpha (aquatic life habits); Gerromorpha (mostly semi-aquatic life habits); Saldidae (the relatively rare species have a relatively big ratio); Miridae (usually on plants), Reduviidae (the 
relatively rare species and those on plants, in buildings etc. have a relatively big ratio); Aradidae (usually under bark), Rhopalidae (usually on plants).

The three families, which are more or less rich in species and have the highest ratio of extracted species, are Rhyparochromidae (50.65\%), Tingidae (37.50\%) and Nabidae (31.25\%). Out of them, the family Rhyparochromidae is the most diverse and most characteristic at the ground-level. Most tingid species have been collected in very low numbers, only some members of the genera Campylosteira and Acalypta have been extracted in great numbers. The number of the nabid specimens has also been low.

The three families having the highest ratio of extracted individuals are Tingidae (40.74\% of the total specimens), Hebridae (19.90\%) and Rhyparochromidae (11.59\%). Out of the family Tingidae, the Campylosteira and Acalypta species - first of all $A$. musci - are the most characteristic, often occurring in great numbers in ground substrata. Specimens of the 2 Campylosteira and the 7 Acalypta species represent $94.96 \%$ of the total tingid specimens extracted. Out of the species of these two genera, A. musci was the most dominant, having a relative dominance of $41.80 \% .97 .60 \%$ of the total hebrid specimens belong to the species Hebrus ruficeps. This species seems to be characteristic at the ground-level of suitable (mostly riparian or other humid) plant communities. The family Rhyparochromidae, containing mainly seed-feeder species, occurs widely at the ground-level.

By exploring the zoogeographic distribution of the heteropteran species collected in the Hungarian provinces, the followings have been concluded. In case of the province Eupannonicum (except district Arrabonicum) is the percentage of the species with Mediterranean and Ponto-Mediterranean distribution especially high $(8.33 \%$ of the species, $8.16 \%$ of the specimens). No boreo-montaneous species have been found in this area. The total ratio of the West-Palaearctic, European and Euro-Mediterranean species is the lowest $(25.00 \%$ of the species, $17.55 \%$ of the specimens), whereas that of the Eurosiberian, South-Eurosiberian and West-Eurosiberian species is the highest $(40.28 \%$ of the species, $61.02 \%$ of the specimens) in this area out of the three examined phytogeographical provinces. Consequently, the ground-living bug assemblage of the province Eupannonicum has a relation to the considerable continental and a far less important subatlantic climatic influence of this area.

In the province Bakonyicum, the ratio of the Mediterranean and PontoMediterranean elements is lower than in the province Eupannonicum (4.81\% of the species, $6.05 \%$ of the specimens). Two species with boreo-montaneous distribution have also been found (Megalonotus antennatus, Tytthus pygmaeus; $2.41 \%$ of the species, $0.29 \%$ of the specimens). The total percentage of the West-Palaearctic, European and Euro-Mediterranean species is relatively low $(42.17 \%$ of the species, $63.40 \%$ of the specimens), whereas that of the Eurosiberian, South-Eurosiberian and West-Eurosiberian species is high $(26.50 \%$ of the species, $28.82 \%$ of the specimens) in this province.

Also in the phytogeographic province Matricum, the percentage of the Mediterranean and Ponto-Mediterranean species is far less than in the province Eupannonicum $(5.27 \%$ of the species, $0.52 \%$ of the specimens). Two boreo-montaneous elements have been found in this area (Megalonotus antennatus, Monalocoris filicis; $2.63 \%$ of the species, $0.26 \%$ of the specimens). The total percentage of the WestPalaearctic, European and Euro-Mediterranean species is relatively low (40.79\% of the species, $50.93 \%$ of the specimens), whereas that of the Eurosiberian, South- 
Eurosiberian and West-Eurosiberian species is high $(26.32 \%$ of the species, $31.64 \%$ of the specimens) in this area.

As a summary, in respect to the environmental changes through the country, different parallel changes can be observed in the zoogeographical distribution of the groundliving heteropteran communities of the different provinces. The percentage of the fauna elements indicating continentality (Eurosiberian, South-Eurosiberian and WestEurosiberian) is the highest in the province Eupannonicum. Their ratio is far lower in the two hilly provinces. The percentage values of the species preferring humid subatlantic climate (West-Palaearctic, European and Euro-Mediterranean) show an increase in the direction Eupannonicum $\rightarrow$ Matricum $\rightarrow$ Bakonyicum, consequently are the highest in the western part of the country. The Mediterranean and PontoMediterranean fauna elements have been collected in the lowlands (province Eupannonicum) in greatest number. Boreo-montaneous elements have been found only in the two hilly provinces (Bakonyicum and Matricum).

Acknowledgements. We are very grateful to Prof. Dr. K. Dózsa-Farkas for providing Dr I. Loksa's collection, thereby making our investigations possible; to Dr. E. Kondorosy for providing his unpublished zoogeographical data; to Ms. M. Rédei-Szerencsi and Ms. T. Tölgyesi-Nell for technical help at various phases of the project. At last, but in the first place of course, we would like to express our special thanks to the late Dr. I. Loksa (1923-1992), eminent Hungarian zoologist, former head of the Department of Systematic Zoology and Ecology of the Eötvös Loránd University, researcher of many soil-inhabiting invertebrate groups, especially Arachnoidea and Myriapoda. Without his pioneering and assiduous activity on the research of the soil fauna of Hungary it would have been impossible to implement our work.

\section{REFERENCES}

[1] Aukema, B. (1990): Additional data on the Heteroptera fauna of the Kiskunság National Park. - Folia entomologica hungarica 51: 5-16.

[2] Aukema, B. \& Rieger, Chr. (eds.) (1995): Catalogue of the Heteroptera of the Palaearctic Region. Vol. 1. Enicocephalomorpha, Dipsocoromorpha, Nepomorpha, Gerromorpha, Leptopodomorpha. - The Netherlands Entomological Society, Amsterdam, i-xxvi, 1-222.

[3] Aukema, B. \& Rieger, Chr. (eds.) (1996): Catalogue of the Heteroptera of the Palaearctic Region. Vol. 2. Cimicomorpha I. - The Netherlands Entomological Society, Amsterdam, i-xiv, 1-361.

[4] Aukema, B. \& Rieger, Chr. (eds.) (1999): Catalogue of the Heteroptera of the Palaearctic Region. Vol. 3. Cimicomorpha II. - The Netherlands Entomological Society, Amsterdam, i-xiv, 1-577.

[5] Aukema, B. \& Rieger, Chr. (eds.) (2001): Catalogue of the Heteroptera of the Palaearctic Region. Vol. 4. Pentatomomorpha I. - The Netherlands Entomological Society, Amsterdam, i-xiv, 1-346.

[6] Bakonyi, G., Csölle, C., Fabók, V., Földessy, M., Hufnagel, L., Kondorosy, E., Rédei, D., Tölgyesiné-Nell, T., Varga, I. \& Vásárhelyi, T. (2002): The Heteroptera fauna of the Fertő-Hanság National Park. - In: Mahunka, S. (ed.): The Fauna of the Fertö-Hanság National Park, II: 325-350. Magyar Természettudományi Múzeum, Budapest.

[7] Bakonyi, G. \& Vásárhelyi, T. (1981): Contribution to the Heteroptera fauna of the Hortobágy National Park, I. - In: Mahunka, S. (ed.): The Fauna of the Hortobágy National Park, I: 55-63. Akadémiai Kiadó, Budapest.

[8] Bakonyi, G. \& Vásárhelyi, T. (1987): The Heteroptera fauna of the Kiskunság National Park. - In: Mahunka, S. (ed.): The Fauna of the Kiskunság National Park, II: 85-106. Akadémiai Kiadó, Budapest. 
[9] Bakonyi, G. \& Vásárhelyi, T. (1993): Aquatic and semiaquatic bugs of the Bükk National Park (Heteroptera: Nepomorpha and Gerromorpha). - In: Mahunka, S. (ed.): The Fauna of the Bükk National Park, I: 65-69. Magyar Természettudományi Múzeum, Budapest.

[10] Benedek, P. (1964): Adatok a Tapolca-patak és környéke rovarfaunájához II. [Data to insect fauna of the Tapolca Brook II.] - Folia entomologica hungarica 17: 265-282. [in Hungarian]

[11] Benedek, P. (1967): Faunisztikai, etológiai és tápnövény adatok magyarországi Pentatomoidea (Heteroptera) fajokról. [Faunistical, ethological, ecological and food-plant data of Pentatomoid (Heteroptera) species in Hungary.] - Folia entomologica hungarica 20: 475-519. [in Hungarian]

[12] Benedek, P. (1969a): A Nabidae család (Heteroptera) fajainak elterjedése a Kárpátmedencében. [Distribution of the species of the family Nabidae (Heteroptera) in the Carpathian Basin.] - Állattani Közlemények 56: 7-16. [in Hungarian]

[13] Benedek, P. (1969b): A Velia Latreille, 1804 génusz (Heteroptera, Veliidae) kárpátmedencei fajai. [Species of the genus Velia Latreille, 1804 (Heteroptera, Veliidae) in the Carpathian Basin.] - Folia entomologica hungarica 22: 256-259. [in Hungarian]

[14] Benedek, P. (1969c): Poloskák VII.-Heteroptera VII. - In: Magyarország Állatvilága (Fauna Hungariae), XVII, 7: 1-86. Akadémiai Kiadó, Budapest. [in Hungarian]

[15] Benedek, P. (1970a): The larvae and phenology of the Hungarian nabids (Heteroptera). Acta Zoologica Academiae Scientiarum Hungaricae 16(3-4): 357-366.

[16] Benedek, P. (1970b): The semiaquatic Heteroptera of the Carpathian Basin with notes on the distribution and the phenology of the species. - Faunistische Abhandlungen herausgegeben vom Staatlichen Museum für Tierkunde in Dresden 3: 27-49.

[17] Bíró, J. \& Hufnagel, L. (2001): Heteroptera fajok a Balaton vízrendszerében. [Heteroptera species in the basin of Lake Balaton.] - Folia Musei historico-naturalis Bakonyiensis 17: 111-118. [in Hungarian]

[18] Földessy, M. (1987): Adatok a Mátra-hegység Heteroptera faunájához I. [Data to the Heteroptera fauna of Mátra Mountains (Hungary), Part I.] - Folia Historico Naturalia Musei Matrensis 12: 47-52. [in Hungarian]

[19] Földessy, M. (1988a): A Mátra Múzeum Heteroptera gyüjteménye. [Heteroptera collection of the Mátra Museum.]- Folia Historico Naturalia Musei Matrensis 2: 65-69. [in Hungarian]

[20] Földessy, M. (1988b): A Sár-hegy Heteroptera faunája. [Heteroptera fauna of Sár-hegy.] - Folia Historico Naturalia Musei Matrensis, suppl. 2: 9-12. [in Hungarian]

[21] Földessy, M. (1991): A Sár-hegy Heteroptera faunájának állatföldrajzi vizsgálata. [Zoogeographical investigation of the Heteroptera fauna of Sár-hegy (Sár Hill).] - Folia Historico Naturalia Musei Matrensis 16: 71-73. [in Hungarian]

[22] Földessy, M. (1992a): Adatok a Boronka-melléki Tájvédelmi körzet poloska (Heteroptera) faunájához. [Facts for the plant bug's appearance (Heteroptera) in Nature Conservation Area of Boronka region.] - Dunántúli Dolgozatok Természettudományi Sorozat 7: 101-106. [in Hungarian]

[23] Földessy, M. (1992b): Data to the Heteroptera fauna of South Transdanubia, Hungary. A Janus Pannonius Múzeum Évkönyve 37: 13-17.

[24] Földessy, M. (1998): Data to the Heteroptera fauna of the Bükk Mts N Hungary. - Folia entomologica hungarica 59: 35-52.

[25] Földessy, M. (1999): Heteroptera fauna elterjedése a Bükk hegységben (ÉszakMagyarország). [Status and directions of faunistic research of Heteroptera in the BükkMountains.] - Folia Historico Naturalia Musei Matrensis 23: 191-230. [in Hungarian]

[26] Földessy, M., Vásárhelyi, T. \& Bakonyi, G. (1999): Data to the Heteroptera fauna of the Aggtelek National Park. - In: Mahunka, S. (ed): The Fauna of the Aggtelek National Park, I: 119-126. Magyar Természettudományi Múzeum, Budapest. 
[27] Franz, H. (1948): Zur Kenntnis der Bodenfauna im pannonischen Klimagebiet Österreichs. II. Arthropoden. - Annalen des Naturhistorischen Museums in Wien 8: 440549.

[28] Gebhardt, A. (1957): Faunisztikai és állatföldrajzi adatok a Mecsek-hegység és a Harsányi-hegység Hemiptera állományának ismeretéhez. [Faunistical and zoogeographical data to the knowledge of the Hemiptera species in Mecsek and Harsányi-Mountains.] - Folia entomologica hungarica 10: 301-340. [in Hungarian]

[29] Halászfy, É. (1953): Bátorliget szipókás-faunája - Rhynchota. [The Rhynchota fauna of Bátorliget.] - In: Székessy, V. (ed.): Bátorliget élővilága. [The Natural Life of Bátorliget.] Akadémiai Kiadó, Budapest, 395-401. [in Hungarian]

[30] Halászfy, É. (1954): Magyarország és a környező területek Brachyplatida és Cydnida fajainak ökológiája és elterjedése. [The ecology and distribution of the Brachyplatidae and Cydnidae species of Hungary and the neighbouring countries.] - Folia entomologica hungarica 7: 93-132. [in Hungarian]

[31] Halászfy, É. (1955): Magyarország és a környező területek Scutellerida (Scutellerinae) fajainak ökológiája és elterjedése. [The ecology and distribution of the Scutelleridae (Scutellerinae) species of Hungary and the neighbouring countries.] - Folia entomologica hungarica 8: 73-94. [in Hungarian]

[32] Halászfy, É. (1959): Poloskák II.-Heteroptera II. - In: Magyarország Állatvilága (Fauna Hungariae), XVII, 2: 1-87. Akadémiai Kiadó, Budapest. [in Hungarian]

[33] Harmat, B. (1986a): A Bakony-hegység karimáspoloska faunájának alapvetése (Heteroptera: Coreidae). [On the Coreidae fauna of the Bakony Mountains.] - Folia Musei historico-naturales Bakonyiensis 5: 7-12. [in Hungarian]

[34] Harmat, B. (1986b): Ritkábban előforduló poloskafajok a Bakonyból (Heteroptera). [Some rare Heteroptera species from the Bakony Mountains.] - Folia Musei historiconaturales Bakonyiensis 5: 13-16. [in Hungarian]

[35] Harmat, B. (1989): A Bakony-hegység Alydidae, Rhopalidae és Stenocephalidae faunájának alapvetése (Heteroptera). [On the Alydidae, Rhopalidae and Stenocephalidae from the Bakony Mountains.] - Folia Musei historico-naturales Bakonyiensis 8: 11-18. [in Hungarian]

[36] Harmat, B. (1993): A Bakony-hegység Nabidae, Reduviidae és Pyrrhocoridae faunájának alapvetése (Heteroptera). [On the Nabidae, Reduviidae and Pyrrhocoridae fauna of the Bakony Mountains.] - Folia Musei historico-naturales Bakonyiensis 12: 23-38. [in Hungarian]

[37] Henry, T. J. (1997): Phylogenetic analysis of family groups within the infraorder Pentatomomorpha (Hemiptera: Heteroptera), with emphasis on the Lygaeoidea. - Annals of the Entomological Society of America 90(3): 275-301.

[38] Horváth, G. (1881): Hemiptera nova vel minus cognita. I. - Természetrajzi Füzetek 5: $39-42,217-225$.

[39] Horváth, G. (1900): Ordo Hemiptera. - In: Paszlavszky, J. (ed.): A Magyar Birodalom Állatvilága (Fauna Regni Hungariae), III. (Arthropoda). A K. M. Természetudományi Társulat, Budapest, 1-72.

[40] Horváth, G. (1906): Synopsis Tingitidarum Regionis palaearcticae. - Annales historiconaturales Musei nationalis Hungarici 4: 1-117.

[41] Horváth, G. (1907): Supplementum ad Faunam Hemipterorum Regni Hungariae. Annales historico-naturales Musei nationalis Hungarici 5: 501-506.

[42] Hufnagel, L. (1994): Adatok a Naplás-tó és környéke élővilágához III. A Naplás-tó és környéke vízi és vízfelszíni poloskafaunája. [Data to the knowledge of the natural life of the Lake Naplás III. Aquatic and semiaquatic bugs of the Lake Naplás and its environs.] Calandrella 8(1-2): 94-102. [in Hungarian] 
[43] Hufnagel, L. (1998): Data to the knowledge of the aquatic, semiaquatic and shore bug fauna of Budapest and the county Pest (Heteroptera: Nepomorpha, Gerromorpha, Leptopodomorpha). - Folia entomologica hungarica 59: 29-34.

[44] Kis, B. (1984): Heteroptera. Partea generală şi suprafamilia Pentatomoidea. In: Fauna Republicii Socialiste România VIII, 8: 1-216. Editura Academiei Republicii Socialiste România, Buçuresti. [in Roumanian]

[45] Kis, B. \& Kondorosy, E. (in press): Poloskák IV.-Heteroptera IV. - In: Magyarország Állatvilága (Fauna Hungariae), XVII, 4. [in Hungarian]

[46] Kondorosy, E. (1999): Checklist of the Hungarian bug fauna (Heteroptera). - Folia entomologica hungarica 60: 125-152.

[47] Kondorosy, E. (2001): Somogy megye poloskafaunája (Heteroptera). [Bug fauna of Somogy county (Heteroptera).] - Natura Somogyiensis 1: 123-134. [in Hungarian]

[48] Kondorosy, E. \& Földessy, M. (1998): Adatok a Duna-Dráva Nemzeti park Dráva menti területei poloska (Heteroptera) faunájához. [Data to the Heteroptera fauna of the areas along river Dráva in the Duna (Danube)-Dráva National Park.] - In: Uherkovich, Á. (ed.): A Dráva mente állatvilága, II. Dunántúli Dolgozatok Természettudományi Sorozat 9: 159-176. [in Hungarian]

[49] Kondorosy, E. \& Harmat, B. (1998): Contribution to the knowledge to the Heteroptera fauna of the Örség Landscape Conservation Area. - In: Víg, K. (ed.): Az Örségi Tájvédelmi Körzet természeti képe III. [Natural history of Örség Landscape Conservation Area III.] - Savaria, a Vas megyei Múzeumok Értesítője (Pars historico-naturalis) 24(2): $25-49$.

[50] Kondorosy, E. \& Kis, B. (1996): Data to the knowledge of the Lygaeidae (Heteroptera) of the Bükk National Park. - In: Mahunka, S. (ed.): The Fauna of the Bükk National Park: 147-150. Magyar Természettudományi Múzeum, Budapest.

[51] Moldoványi, L. (1977): Adatok a hortobágyi vizek poloskafaunájának ismeretéhez (Heteroptera). [Data to the knowledge on the bug fauna of waters of Hortobágy.] - Folia entomologica hungarica 30(2): 77-82. [in Hungarian]

[52] Moldoványi, L. (1984): Faunisztikai vizsgálatok a Rakaca tározó poloskáin (Heteroptera). [Faunistical investigations on the Heteropterous insects of the Rakaca storage-lake (NE Hungary).] - Folia entomologica hungarica 45(1): 231-235. [in Hungarian]

[53] Péricart, J. (1972): Hémiptères Anthocoridae, Cimicidae et Microphysidae de l'Ouestpaléarctique. In: Faune de l'Europe et du bassin méditerranéen, 7: i-iv, 1-404. Masson et Cie Éditeurs, Paris.

[54] Péricart, J. (1983): Hémiptères Tingidae Euro-Méditerranéens. In: Faune de France, France et régions limitrophes, 69: 1-618. Fédération Française des Sociétés de Sciences Naturelles, Paris.

[55] Péricart, J. (1999a): Hémiptères Lygaeidae Euro-Méditerranéens. 1. In: Faune de France, France et régions limitrophes, 84A. Fédération Française des Sociétés de Sciences Naturelles, Paris, i-xx, 1-468.

[56] Péricart, J. (1999b): Hémiptères Lygaeidae Euro-Méditerranéens. 2. In: Faune de France, France et régions limitrophes, 84B. Fédération Française des Sociétés de Sciences Naturelles, Paris, i-vi, 1-453.

[57] Péricart, J. (1999c): Hémiptères Lygaeidae Euro-Méditerranéens. 3. In: Faune de France, France et régions limitrophes, 84C. Fédération Française des Sociétés de Sciences Naturelles, Paris, i-vi, 1-487.

[58] Rédei, D. \& Hufnagel, L. (2003): Beiträge zur Kenntnis der Dipsocoromorpha-Arten (Insecta: Heteroptera) in Ungarn. - Opuscula zoologica Instituti zoosystematici et oecologici Universitatis Budapestinensis 34 (2002): 67-76.

[59] Soó, R. (1965): Növényföldrajz. [Phytogeography.] - Tankönyvkiadó, Budapest, 1-152, I-XXV. [in Hungarian] 
[60] Soós, Á. (1963): Poloskák VIII.-Heteroptera VIII. - In: Magyarország Állatvilága (Fauna Hungariae), XVII, 8: 1-48. Akadémiai Kiadó, Budapest. [in Hungarian]

[61] Vásárhelyi, T. (1974): Új és kevéssé ismert csipkéspoloskák a magyar faunában (Heteroptera: Tingidae). [New and little-known lace bugs in the Hungarian fauna (Heteroptera: Tingidae).] - Folia entomologica hungarica 27(2): 231-234. [in Hungarian]

[62] Vásárhelyi, T. (1978): Poloskák V.-Heteroptera V. - In: Magyarország Állatvilága (Fauna Hungariae), XVII, 5: 1-76. Akadémiai Kiadó, Budapest. [in Hungarian]

[63] Vásárhelyi, T. (1983a): Contribution to the Heteroptera fauna of the Hortobágy National Park, II. - In: Mahunka, S. (ed.): The Fauna of the Hortobágy National Park, II: 125-131. Akadémiai Kiadó, Budapest.

[64] Vásárhelyi, T. (1983b): Poloskák III.-Heteroptera III. - In: Magyarország Állatvilága (Fauna Hungariae), XVII, 3: 1-88. Akadémiai Kiadó, Budapest. [in Hungarian]

[65] Vásárhelyi, T. (1985): A Barcsi borókás poloskafaunájának alapvetése (Heteroptera). Dunántúli Dolgozatok Természettudományi Sorozat 5: 101-104. [in Hungarian]

[66] Vásárhelyi, T. (1990): Poloska lárvák családhatározója (Heteroptera). [Family-key to the larvae of true bugs of Hungary.] - Folia entomologica hungarica 51: 149-161. [in Hungarian]

[67] Vásárhelyi, T. \& Bakonyi, G. (1987): A Balaton vizén és víztükrén élő poloskák (Heteroptera). [Aquatic and semiaquatic bugs of the Lake Balaton (Heteroptera).] - Folia entomologica hungarica 49: 240-242. [in Hungarian]

[68] Vásárhelyi, T., Kondorosy, E. \& Bakonyi, G. (1990): The Heteroptera fauna of the Bátorliget Nature Reserves. - In: Mahunka, S. (ed.): The Bátorliget Nature Reserves after forty years, 2: 347-355. Magyar Természettudományi Múzum, Budapest.

[69] Wagner, E. (1952): Blindwanzen oder Miriden. - In: Dahl, F. (ed.): Die Tierwelt Deutschlands und der angrenzenden Meeresteile, 41: i-iv, 1-218. Gustav Fischer Verlag, Jena.

[70] Wagner, E. (1967): Wanzen oder Heteropteren. II. Cimicomorpha. - In: Dahl, F. (ed.): Die Tierwelt Deutschlands und der angrenzenden Meeresteile, 55: i-iv, 1-179. Gustav Fischer Verlag, Jena.

[71] Wagner, E. (1974a): Die Miridae Hahn, 1831, des Mittelmeerraumes und der Makaronesischen Inseln (Hemiptera, Heteroptera). Teil 1. - Entomologische Abhandlungen herausgegeben vom Staatlichen Museum für Tierkunde Dresden 37, Suppl. (1970-71): i-ii, 1-484.

[72] Wagner, E. (1974b): Die Miridae Hahn, 1831, des Mittelmeerraumes und der Makaronesischen Inseln (Hemiptera, Heteroptera). Teil 2. - Entomologische Abhandlungen herausgegeben vom Staatlichen Museum für Tierkunde Dresden 39, Suppl. (1973): i-ii, 1-421.

[73] Wagner, E. (1975): Die Miridae Hahn, 1831, des Mittelmeerraumes und der Makaronesischen Inseln (Hemiptera, Heteroptera). Teil 3. - Entomologische Abhandlungen herausgegeben vom Staatlichen Museum für Tierkunde Dresden 40, Suppl.: i-ii, 1-483.

[74] Wagner, E. \& Weber, H.H. (1978): Die Miridae Hahn, 1831, des Mittelmeerraumes und der Makaronesischen Inseln (Hemiptera, Heteroptera). Nachträge zu den Teile 1-3. Entomologische Abhandlungen herausgegeben vom Staatlichen Museum für Tierkunde Dresden 42, Suppl.: i-ii, 1-96. 